\title{
Does the Federal Reserve Invest Member Bank Reserves?
}

\author{
ALBERT E. BURGER
}

\begin{abstract}
T 1 $\mathrm{HE}$ Federal Reserve Banks earned $\$ 6.9$ billion in 1977. How are the Federal Reserve Banks able to "earn" this amount of income? One popular misconception is that the Federal Reserve Banks earn income by investing member bank reserves. In fact, earnings of the Federal Reserve Banks are not the result of the volume of member bank reserves, but that bank reserves and eamings of the Federal Reserve Banks are both by-products of the way a central bank operates.
\end{abstract}

Commercial banks that are members of the Federal Reserve System are required to hold a specified amount of reserves for each dollar of deposit liabilities. ${ }^{1}$ They hold the bulk of these reserves in the form of deposits at their district Federal Reserve Bank. Looked at from the viewpoint of a commercial banker, it appears that this $\$ 28$ billion of member bank deposits at the Federal Reserve Banks forms the basis for Federal Reserve acquisition of earning assets, primarily Government securities. After all, when a commercial bank experiences an inflow of deposits, that bank can expand its holdings of eaming assets, so why shouldn't the analogy hold for Federal Reserve Banks?

Also, frequently when reserve requirement ratios are raised, thereby requiring member banks to hold more deposits at Federal Reserve Banks, Federal Reserve Bank holdings of Government securities (earning assets) rise. Likewise, when reserve requirement ratios are lowered, thereby reducing required reserves, there is usually a decrease in Federal Reserve holdings of Government securities.

These observations have prompted assertions that the Federal Reserve receives substantial earnings

Member bank reserve requirements are computed as a percent of (1) net demand deposits, (2) total time and savings deposits, and (3) selected other liabilities. Net demand deposits are gross demand deposits minus cash items in process of collection and demand balances due from domestic banks. from the reserves that are required of member banks. A question that logically follows from such assertions, then, is why doesn't the Federal Reserve share these reserve-induced earnings with its member banks? After all, wouldn't the Federal Reserve's earnings be slashed if all member banks chose to leave the System?

These conclusions are the result of a faulty analysis of the operations of a central bank. Fundamentally, they result from confusing the way a commercial bank operates with the way a central bank operates. To sort out this confusion one should first answer some questions: how are reserves created, and what causes them to increase or decrease?

\section{Open Market Operabives}

Any one commercial bank can increase its reserves by such actions as buying Federal funds or attracting deposits by some means such as raising interest rates on certificates of deposit. In such situations, what one bank gains another bank loses. Therefore, total bank reserves cannot be changed by commercial banks themselves; the Federal Reserve must become involved in the process. In the U.S. banking system total bank reserves originate primarily from purchases of Government securities by the Federal Reserve (open market operations). The chain of causality runs from the purchase of Government securities (earning assets of the Federal Reserve) to member bank deposits at Federal Reserve Banks, not the other way around.

To see how this process works, consider the case in which the Federal Reserve System purchases Government securities. Assume that the System's Trading Desk at the New York Federal Reserve Bank decides to purchase $\$ 100$ million in Government securities. The Trading Desk would contact the dealers in Government securities, receive their offers, and then arrange the purchase with the dealers offering the lowest price for the securities. The transactions would 
be completed by the Federal Reserve Bank of New York "paying" for the securities by crediting the reserve account of the dealers' banks which, in turn, would credit the dealers' checking accounts.

The results of these transactions are (1) the Federal Reserve System's holdings of Government securities have risen, (2) bank deposits at the Federal Reserve Bank of New York (bank reserves) have increased, and (3) demand deposits of the public have risen. The Federal Reserve has acquired the Government securities by "creating" a liability on itself, the demand deposits owed to the member banks (bank reserves). As a by-product of the process, Federal Reserve earnings will be increased as a result of the interest the Federal Reserve will collect from the increased holdings of Government securities. ${ }^{2}$

\section{Reserve Requirements}

To clarify further these points, consider the case in which the Board of Governors of the Federal Reserve System raises required reserve ratios for member banks. This action does not change the total reserves of the banking system. Just because required reserves are larger than before does not mean that total reserves are larger. In this case, the initial effect of the Federal Reserve action is to make required reserves larger than total reserves. Member banks can only continue to maintain their existing structure of deposit liabilities if they increase their reserves, that is, deposits at Federal Reserve Banks.

Two atternative results could follow. Following one course of action, the Federal Reserve might decide not to offset the effect of the higher reserve requirement ratios on deposits. In this case something must "give," since required reserves are larger than total reserves. What gives is total deposits; they contract through the process by which each bank attempts to build up its reserves by selling securities and reducing loans. This process continues until the existing amount of total reserves equals required reserves on the new lower volume of bank deposits. Total member bank deposits at the Federal Reserve Banks are unchanged and

2For a detailed discussion of open market operations and their effeets on bank reserves, see Paul Meek, Open Market Operations, Federal Reserve Bank of New York (May 1973), and Dorothy M. Nichols, Modern Money Mechanics: A Workbook on Deposits, Currency, and Bank Reserves, Federal Reserve Bank of Chicago (June 1975). earning assets of the Federal Reserve are unchanged, but bank credit and the monetary aggregates $\mathrm{Ml}$ and $\mathrm{M} 2$ are lower. This is a case where an increase in reserve requirements does not increase the earnings of the Federal Reserve System.

Alternatively, the Federal Reserve might decide to offset the short-run impact on bank deposits of the increase in reserve requirement ratios. In such a case the Federal Reserve would buy Government securities and, as a result of this action, member bank deposits at Federal Reserve Banks would rise. Earning assets held by the Federal Reserve would be higher than before, not because of a rise in reserve requirements and member bank deposits, but simply because the central bank chose to offset the impact of the change in reserve requirement ratios on total member bank deposits. These examples indicate that increases in member bank reserves are in no way the causal factor in increases of the Fed's earning assets. Member bank reserves and the Fed's earning assets change simultaneously as a result of policy decisions.

As a final example, consider a case where there were no member banks. Assume even further that there were no legal restrictions that required banks to hold deposits at Federal Reserve Banks. Would the ability of the Federal Reserve Banks to generate their own earnings be affected? The answer is no. To implement its monetary policy objectives, the Federal Reserve would still buy and sell Government securities. Its holdings of Government securities would still represent the primary source of the "base" under bank deposits. ${ }^{3}$ The Federal Reserve would pay for the securities just as it does now, with a check written on itself. Commercial banks would be "paid" when they presented the check for collection, either by receiving a deposit at a Federal Reserve Bank or currency (Federal Reserve notes). This is exactly the same way they are "paid" today. In this case, however, it would be crystal clear that the connection between bank reserves and the volume of Federal Reserve earning assets is not causal, but only a simultaneous balance sheet necessity. Thus, whatever the merits of arguments for payment of interest on member bank reserves, the contention that reserves are the source of Federal Reserve earnings is not one of them.

\footnotetext{
${ }^{3}$ See Anatol B. Balbach and Albert E. Burger, "Derivation of the Monetary Base," this Review (November 1976), pp. 2-8.
} 